\title{
Production, Characterization, and Immunohistochemical Application of Monoclonal Antibodies to Glutaminase Purified from Rat Brain
}

\author{
Takeshi Kaneko, Yoshihiro Urade, ${ }^{1}$ Yasuyoshi Watanabe, ${ }^{1}$ and Noboru Mizuno \\ Department of Anatomy (1st Division), Faculty of Medicine, Kyoto University, Kyoto 606, Japan, and 'Hayaishi \\ Bioinformation Transfer Project, Research Development Corporation of Japan, Kyoto 601, Japan
}

\begin{abstract}
Monoclonal antibodies were produced against phosphateactivated glutaminase (EC 3.5.1.2) as a marker for glutamatergic neurons: The enzyme was purified 1000 -fold from rat brain mitochondria with a recovery of $27 \%$. Upon SDSPAGE the purified enzyme showed a single band up to 1.7 $\mu \mathrm{g}$ after the silver staining at molecular weight 62,000 . Two monoclonal antibodies (IgMs) were produced; these absorbed more than $90 \%$ of glutaminase activity in rat brain homogenate. In immunoblotting after PAGE of the homogenate, the antibodies recognized only 1 protein band at the same position as that of the purified enzyme. Thus, the antibodies are specific and sufficient markers for glutaminase.

Many neuronal cells in the rat brain were labeled immunohistochemically with these antibodies, but non-neuronal elements such as glial cells and vessels were not. Intense labeling was consistently observed in putative glutamatergic neurons such as pyramidal cells of layers $V$ and $V I$ in the cerebral neocortex. Intense staining was also seen in possible mossy fiber endings in the granular layer of the cerebellar cortex and in neurons giving off mossy fibers such as those in the pontine nuclei, pontine tegmental reticular nucleus of Bechterew, lateral reticular nucleus of the medulla oblongata, and external cuneate nucleus.
\end{abstract}

L-Glutamate is assumed to be one of the major excitatory neurotransmitters in the mammalian CNS, and the regional distribution of glutamatergic neurons in the brain has been studied by measuring content, release, and uptake of glutamate (for reviews, Watkins and Evans, 1981; Fonnum, 1984) or by autoradiography of L-glutamate binding sites (Greenamyre et al., 1984; Halpain et al., 1984). Recently, Otterson and StormMathisen (1984) raised antisera against glutamate conjugated to BSA and demonstrated glutamate-like immunoreactivity in pyramidal cells in the cerebral neocortex and other neurons in mouse and rat brains. According to these authors, however, the immunoreactivity reveals the "metabolic pool" as well as the "transmitter pool" of glutamate in the brain. Therefore, a specific marker for the transmitter pool of glutamate is necessary to identify glutamatergic neurons.

\footnotetext{
Received Apr. 14, 1986; revised June 20, 1986; accepted June 20, 1986.

We wish to thank President O. Hayaishi of Osaka Medical College, Dr. S. Ito, Dr. N. Yumoto, T. Tanaka, and N. Fujimoto of Hayaishi Bioinformation Transfer Project for their helpful advice and discussions. The technical assistance of $Y$ Yamamoto and the photographic help of A. Uesugi are gratefully acknowledged. Supported in part by grant-in-aid from the Ministry of Education, Science and Culture of Japan (Nos. 59480095, 61131004)

Correspondence should be addressed to Dr. Takeshi Kaneko at the above address.
}

Copyright (C) 1987 Society for Neuroscience $0270-6474 / 87 / 010302-08 \$ 02.00 / 0$
Since the transmitter pool of glutamate is mainly supplied from glutamine (Bradford et al., 1978, 1983; Reubi et al., 1978; Hamberger et al., 1979a, b; Reubi, 1980), glutamatergic neurons are expected to contain glutaminase, which catalyzes the hydrolytic cleavage of L-glutamine to form L-glutamate and ammonium ions. Therefore, phosphate-activated glutaminase (PAG, L-glutamine amidohydrolase, EC 3.5.1.2), a main isozyme of glutaminase in the brain (Kvammc, 1983), is a good marker for glutamatergic neurons. Recently, Altshuler et al. (1984) reported the presence of PAG-like immunoreactivity in the auditory nerve using an antiserum raised against the glutaminase of the rat kidney. In their study, the glutaminase immunoprecipitated with the antiserum showed some heterogeneity on SDS-PAGE. Although they ascribed the heterogeneity to the proteolytic degradation of the enzyme, it may result from the lower specificity of the polyclonal antiserum. To avoid this possibility, an attempt was made to prepare monoclonal antibodies against brain PAG. We purified PAG from rat brain, produced monoclonal antibodies against the enzyme, and then applied them to immunohistochemical staining.

\section{Materials and Methods}

\section{Enzyme assay}

The assay mixture contained $15 \mathrm{~mm}$ boric acid, $250 \mathrm{~mm}$ potassium phosphate $(\mathrm{pH} 8.0)$, and enzyme in a total volume of $50 \mu \mathrm{l}$ except as noted. After preincubation at $25^{\circ} \mathrm{C}$ for $30 \mathrm{~min}$, the reaction was started by the addition of ${ }^{14} \mathrm{C}(\mathrm{U})$-L-glutamine $(0.12 \mu \mathrm{Ci})$ at a final concentration of $15 \mathrm{~mm}$ and incubated at $25^{\circ} \mathrm{C}$ for $3 \mathrm{~min}$. The incubation was terminated by the addition of $50 \mu \mathrm{l}$ of ice-cold ethanol. The glutamic acid formed was separated from glutamine by the method of Prusiner and Milner (1970). Briefly, the solution was mixed with $0.9 \mathrm{ml}$ of $200 \mathrm{~mm}$ acetate- $\mathrm{NaOH}(\mathrm{pH} \mathrm{4.5)}$ and applied to a $5.5 \times 10 \mathrm{~mm}$ Dowex 1-X8 (analytical grade, acetate form, 200-400 mesh) column. The column was washed with $6 \mathrm{ml}$ of distilled water to remove glutamine, and glutamic acid was then eluted with $2 \mathrm{ml}$ of $1 \mathrm{~N} \mathrm{HCl}$. The radioactivity of the eluate was determined by Beckman scintillation counter model LS 2800 . In some cases, the reaction products were separated by thinlayer cellulose chromatography in 2-propanol/formic acid/water (40:2: $10, \mathrm{vol} / \mathrm{vol}$ ) as described by Niederwieser (1972) to identify the product as glutamic acid (Niederwieser, 1972). One unit (U) is defined as the amount of enzyme that catalyzes the production of $1 \mu \mathrm{mol}$ glutamic $\mathrm{acid} / \mathrm{min}$. Protein was estimated by the method of Lowry et al. (1951) using BSA as a standard.

\section{Solubilization and purification of $P A G$}

The mitochondrial fraction was chosen for the starting material because PAG was localized principally in mitochondria (Salganicoff and De Robertis, 1965; Neidle et al., 1969). All steps were carried out at $0-4^{\circ} \mathrm{C}$. except as noted.

Step 1: Preparation of rat brain mitochondria. Wistar rats (200-350 $\mathrm{g}$ body weight) were sacrificed by decapitation under anesthesia. Brains $(140 \mathrm{~g})$ were quickly removed, collected on ice, and homogenized in 6 


\begin{tabular}{|c|c|c|c|c|}
\hline Step & $\begin{array}{l}\text { Vol- } \\
\text { ume } \\
\text { (ml) }\end{array}$ & $\begin{array}{l}\text { Total } \\
\text { protein } \\
\text { (mg) }\end{array}$ & $\begin{array}{l}\text { Specific } \\
\text { activity } \\
\text { (U/mg } \\
\text { protein) }\end{array}$ & $\begin{array}{l}\text { Yield } \\
(\%)\end{array}$ \\
\hline Mitochondrial fraction & 140 & 3100 & 0.17 & 100 \\
\hline Solubilization ( $1 \%$ Triton X-100) & 330 & 2200 & 0.27 & 108 \\
\hline Sodium sulfate, $0-1.2 \mathrm{M}$ & 110 & 1400 & 0.39 & 105 \\
\hline Sodium sulfate, $0.6-1 \mathrm{~m}$ & 16 & 240 & 2.2 & 96 \\
\hline Sephacryl S-400 (Tris-HCl) & 174 & 63 & 5.6 & 65 \\
\hline Lysine-Sepharose & 23 & 31 & 8.9 & 51 \\
\hline Sepharose 4B (phosphate-borate) & 18 & 1.2 & 130 & 29 \\
\hline Centrifugation & 2 & 0.9 & 170 & 27 \\
\hline
\end{tabular}

vol of $0.32 \mathrm{~m}$ sucrose containing $5 \mathrm{~mm}$ potassium phosphate ( $\mathrm{pH} 8.0$ ) by using a Potter-Elvehjem glass homogenizer with a Teflon pestle. The homogenate was centrifuged at $1000 \times g$ for $20 \mathrm{~min}$. The nuclear pellet was resuspended with $4 \mathrm{vol}$ of the same solution and centrifuged again. The supernatants were combined and then centrifuged at $10,000 \times g$ for $30 \mathrm{~min}$. The crude mitochondrial pellet was resuspended in $50 \mathrm{~mm}$ Tris- $\mathrm{HCl}(\mathrm{pH} 8.0)$ containing $1 \mathrm{~mm}$ EDTA and $6.4 \mathrm{~mm}$ 2-mercaptoethanol ( $\mathrm{T}$ buffer) to a final volume of $140 \mathrm{ml}$ and stored at $-80^{\circ} \mathrm{C}$ until used.

Step 2: Solubilization. PAG was solubilized with Triton $\mathrm{X}-100$ as described for the renal enzyme (Curthoys et al., 1976). The crude mitochondria were thawed and homogenized in T buffer containing $1 \%$ Triton X-100. The protein concentration was adjusted in the range of $5-10 \mathrm{mg} / \mathrm{ml}$. After incubation for $30 \mathrm{~min}$, the suspension was centrifuged at $90,000 \times g$ for $60 \mathrm{~min}$ and the supernatant recovered.

Step 3: First sodium sulfate fractionation. This step was carried out at room temperature. One and a half volumes of $2 \mathrm{M} \mathrm{Na}_{2} \mathrm{SO}_{4}$ in distilled water was added to the supernatant and stirred for $30 \mathrm{~min}$. After centrifugation at $17,700 \times g$ for $30 \mathrm{~min}$, floating cakes were collected by siphoning off and resuspended in $\mathrm{T}$ buffer to $5-10 \mathrm{mg}$ protein $/ \mathrm{ml}$. Sodium sulfate ( $2 \mathrm{M}$ in distilled water) was added again to the suspension to give a final concentration of $0.6 \mathrm{M}$, stirred for $30 \mathrm{~min}$, and centrifuged at $17,700 \times g$ for $30 \mathrm{~min}$. The infranatant was collected by siphoning off, and sodium sulfate ( $2 \mathrm{M}$ in distilled water) was added to give a final concentration of $1 \mathrm{M}$. The mixture was stirred and centrifuged at 17,700 $\times$ $g$ for $30 \mathrm{~min}$. The precipitate was resuspended in $15 \mathrm{ml}$ of $\mathrm{T}$ buffer containing $1 \%$ Triton $\mathrm{X}-100$ to prevent PAG from aggregating and was dialyzed overnight against 3 changes of 2 liters of T buffer at $4^{\circ} \mathrm{C}$.

Step 4: First gel filtration. After centrifugation at $20,000 \times \mathrm{g}$ for 30 min to remove insoluble materials, the sample was applied to a column $(5 \times 45 \mathrm{~cm})$ of Sephacryl S-400 equilibrated in T buffer. The flow rate was $240 \mathrm{ml} / \mathrm{hr}$.

Step 5: Lysine-Sepharose chromatography. The active fractions obtained from Step 4 were pooled and applied to a column $(1.5 \times 11.5$ $\mathrm{cm}$ ) of lysine-Sepharose equilibrated in $\mathrm{T}$ buffer, at a flow rate of 48 $\mathrm{ml} / \mathrm{hr}$. After the column was washed with $150 \mathrm{ml}$ of T buffer, adsorbed proteins were eluted with $0.5 \mathrm{M}$ potassium phosphate $(\mathrm{pH} 8.0)$ at a flow rate of $32 \mathrm{ml} / \mathrm{hr}$. Triton X-100 molecules of free form were removed from the sample at this step.

Step 6: Second sodium sulfate fractionation. The eluate was incubated with $15 \mathrm{~mm}$ boric acid- $\mathrm{NaOH}\left(\mathrm{pH} 8.0\right.$ ) at $25^{\circ} \mathrm{C}$ for $30 \mathrm{~min}$ to polymerize PAG (Nimmo and Tipton, 1980), and then $1.5 \mathrm{vol}$ of $2 \mathrm{~m}$ sodium sulfate in distilled water was added to the eluate. After incubation at $25^{\circ} \mathrm{C}$ for $30 \mathrm{~min}$, the mixture was centrifuged at $20,000 \times \mathrm{g}$ for $30 \mathrm{~min}$. The pellet was resuspended in $3 \mathrm{ml}$ of $0.5 \mathrm{M}$ potassium phosphate (pH 8.0), $15 \mathrm{~mm}$ boric acid, $1 \mathrm{~mm}$ EDTA, and $6.4 \mathrm{~mm}$ 2-mercaptoethanol (PB buffer), and centrifuged at $1300 \times g$ for $5 \mathrm{~min}$ to remove insoluble materials.

Step 7: Second gel filtration. The supernatant was applied to a column $(2.5 \times 40 \mathrm{~cm})$ of Sepharose 4B equilibrated in PB buffer. The flow rate was $50 \mathrm{ml} / \mathrm{hr}$.

Step 8: Centrifugation. The active fractions were pooled and centrifuged at $271,000 \times g$ for $4 \mathrm{hr}$. The precipitate was resuspended in $2 \mathrm{ml}$ of $50 \mathrm{~mm}$ Tris-acetate ( $\mathrm{pH} \mathrm{8.0),} 1$ mм EDTA, and 6.4 mм 2-mercap-
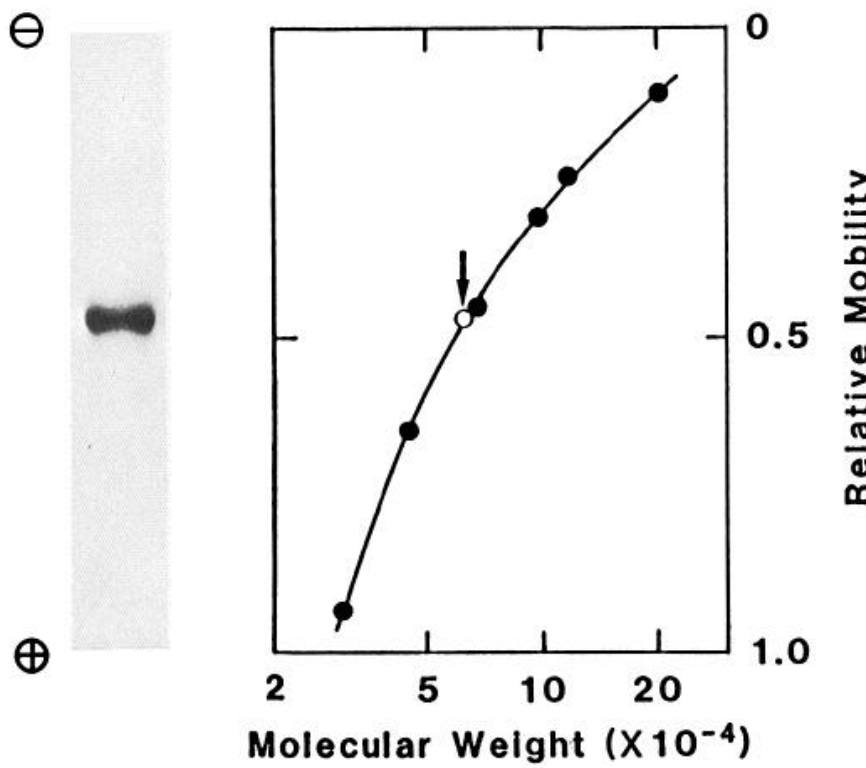

Figure 1. SDS-PAGE. Left, Purified enzyme $(1.7 \mu \mathrm{g})$ was electrophoresed in $10 \%$ polyacrylamide gel in the presence of $0.1 \%$ SDS and stained with silver. Right, The molecular weight of PAG was calculated from the calibration curve to be 62,000 (arrow). The following proteins were used as markers (closed circles): myosin $(200,000), \beta$-galactosidase $(116,250)$, phosphorylase B $(92,500)$, BSA $(66,200)$, ovalbumin $(45,000)$, and carbonic anhydrase $(30,000)$. (The band at the bottom of the gel is the tracking dye, bromophenol blue.)

toethanol, and dialyzed overnight against 2 changes of 1 liter of the same buffer. The solution was centrifuged at $100,000 \times g$ for $30 \mathrm{~min}$, and the pellet was discarded. The final sample was stored at $-80^{\circ} \mathrm{C}$ until employed for immunization.

\section{Production of monoclonal antibodies}

Monoclonal antibodies were produced by the method of Köhler and Milstein (1975). Emulsion of purified PAG $(30 \mu \mathrm{g})$ and complete Freund's adjuvant was injected intraperitoneally to a $\mathrm{BALB} / \mathrm{c}$ mouse. Three weeks after the immunization, a booster shot $(30 \mu \mathrm{g}$ PAG) in incomplete Freund's adjuvant was inoculated. Four weeks after the booster, an intravenous boost with $10 \mu \mathrm{g}$ of PAG in $0.2 \mathrm{ml}$ of saline was carried out. The mouse was sacrificed 3 days after the final injection, and then spleen cells $\left(5 \times 10^{8}\right)$ were fused with $2.5 \times 10^{8}$ myeloma cells P3-NS1/ 1-Ag4-1 (a generous gift from Dr. Y. Nishikawa, Faculty of Medicine, Kyoto University) by the addition of $2 \mathrm{ml}$ of $50 \%$ (wt/vol) polyethylene glycol 4000 . The resulting cell suspension of hybrid was inoculated into three 96-well microtiter plates and fed with selective HAT medium containing $10 \%$ fetal calf serum, $2 \mathrm{~mm}$ L-glutamine, $50 \mu \mathrm{M}$ 2-mercaptoethanol, $0.1 \mathrm{~mm}$ hypoxanthine, $0.4 \mu \mathrm{M}$ aminopterin, and $16 \mu \mathrm{M}$ thymidine in RPMI 1640 medium. Cultures showing hybrid growth were screened for production of anti-PAG antibodies as described below. Positive cells were cloned at least twice by a limiting dilution method.

\section{Detection of anti-PAG antibodies}

A small round nitrocellulose membrane $(6 \mathrm{~mm}$ in diameter) was dotted with $1 \mu \mathrm{l}$ of purified PAG $(30 \mu \mathrm{g} / \mathrm{ml})$ and dried up. The dotted disk was immunostained by the method of Hsu et al. (1981). In a well of a 96well microtiter plate, the membrane was incubated in the following order: (1) with $0.1 \mathrm{ml}$ of PBS containing $10 \%$ normal horse serum for $30 \mathrm{~min}$, (2) with $50 \mu \mathrm{l}$ of culture fluid for $60 \mathrm{~min}$, (3) with $0.1 \mathrm{ml}$ of 27 $\mu \mathrm{g} / \mathrm{ml}$ biotinylated anti-[mouse IgG $(\mathrm{H}+\mathrm{L})] \mathrm{Ig}$, which had $35 \%$ crossreactivity with mouse IgM, in PBS containing $0.3 \%$ Triton X-100 (PBS$\mathrm{X}$ ) for $30 \mathrm{~min}$, (4) with $0.1 \mathrm{ml}$ of avidin-biotinylated peroxidase complex (ABC; Vectastain ABC kit) in PBS-X for 30 min, and (5) with $0.02 \%$ (wt/vol) 3,3'-diaminobenzidine tetrahydrochloride and $0.0045 \%$ hydrogen peroxide in $50 \mathrm{~mm}$ Tris- $\mathrm{HCl}(\mathrm{pH}$ 7.6) (Graham and Karnovski, 1966) for $5 \mathrm{~min}$. All incubations were carried out at room temperature and the membrane was rinsed with PBS-X after each incubation. 


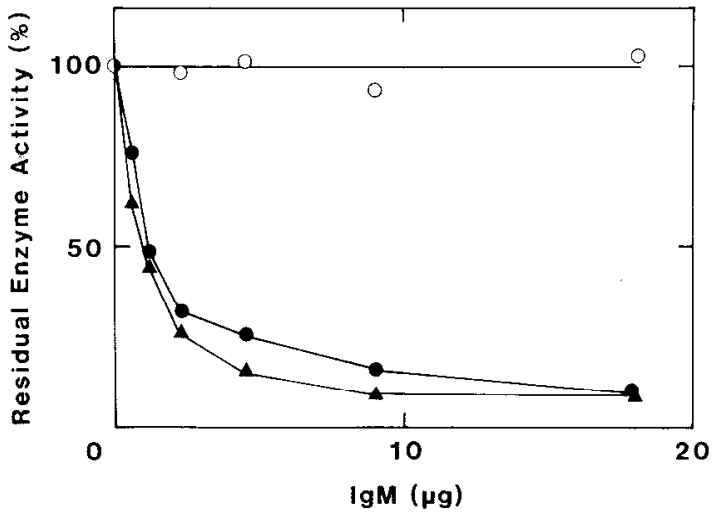

Figure 2. Immunotitration of rat brain PAG with monoclonal antibodies. Crude extract ( $1 \%$ Triton X-100) containing $77 \mathrm{mU}$ of PAG in $0.1 \mathrm{ml}$ was incubated with various amounts of $\mathrm{mAb}-19$ (closed circles) or mAb-21 (closed triangles), and the antibody was adsorbed to Con A-Sepharose gel. After centrifugation, residual PAG activity in the supernatant was assayed. Monoclonal mouse IgM raised against prostaglandin D synthetase was used as a control (open circles).

\section{Typing and purification of antibodies}

Immunoglobulin classes of monoclonal antibodies were identified by using mouse and rat monoclonal typing kits (Serotec) with the Ouchterlony immunodiffusion technique. Ascites tumors were induced by injecting $1 \times 10^{7}$ hybridoma cells into Pristane-primed BALB/c mice intraperitoneally. In order to purify mouse IgM from ascites and culture medium, euglobulin precipitation and gel filtration were employed (Johnstone and Thorpe, 1982).

\section{Immunotitration}

The rat brain was homogenized in $10 \mathrm{vol}$ of $\mathrm{T}$ buffer containing $1 \%$ Triton X-100 and centrifuged at $100,000 \times g$ at $4^{\circ} \mathrm{C}$ for $1 \mathrm{hr}$. Various amounts of antibody or control mouse IgM were added to $100 \mu \mathrm{l}$ of the supernatant containing $77 \mathrm{mU}$ of PAG and stirred at $4^{\circ} \mathrm{C}$ for $1 \mathrm{hr}$. After the incubation, $72 \mu 1$ of concanavalin A (Con A)-Sepharose gel was added to the mixture and stirred again at $4^{\circ} \mathrm{C}$ for $1 \mathrm{hr}$ to trap IgM (Weinstein et al., 1972). After centrifugation at $8000 \times \mathrm{g}$ for $10 \mathrm{~min}$, the supernatant was recovered for PAG assay.

\section{$P A G E$ and immunoblotting}

PAGE in the presence of $0.1 \%$ SDS was carried out by the method of Laemmli (1970). Protein was stained with silver using a commercial kit of Silver Stain Kanto (Kanto reagents, Tokyo, Japan). For the immunoblotting test, the rat brain was homogenized in $10 \mathrm{vol}$ of $62.5 \mathrm{~mm}$ Tris- $\mathrm{HCl}$ (pH 6.8) containing $1 \%$ Triton X-100 and centrifuged at $100,000 \times$ $g$ at $4^{\circ} \mathrm{C}$ for $1 \mathrm{hr}$. The supernatant or purified PAG was applied to $7.5 \%$ PAGE in the presence of $0.1 \%$ Triton-X 100 by using the discontinous buffer system of Davis (1964) or in the presence of SDS as described above. After electrophoresis, proteins were transferred from the gel to Zeta-Probe membrane in $25 \mathrm{~mm}$ Tris- $192 \mathrm{~mm}$ glycine (pH 8.3) by electrophoresis at $60 \mathrm{~V}$ for $3 \mathrm{hr}$ at $4^{\circ} \mathrm{C}$. After the blocking treatment with $10 \%$ normal goat serum in PBS at least for $1 \mathrm{hr}$, the membrane strips cut from the blot (about $4 \mathrm{~mm}$ wide) were incubated overnight with $10 \mu \mathrm{g} / \mathrm{ml}$ monoclonal antibody or mouse myeloma IgM in PBS-X containing $10 \%$ normal goat serum. After being washed, the strips were immunostained by the unlabeled antibody peroxidase-antiperoxidase (PAP) method of Sternberger (1979) with rabbit anti-(mouse IgM) IgG diluted 1/100, goat anti-(rabbit IgG) serum diluted $1 / 50$, and rabbit PAP diluted 1/200. All incubations were performed in PBS-X for $1 \mathrm{hr}$ at room temperature and the blots were rinsed with PBS-X after each incubation. Bound peroxidase was stained with Graham-Karnovski's solution as mentioned above.

\section{Immunohistochemistry}

Wistar rats $(200-350 \mathrm{~g})$ were anesthetized with sodium pentobarbital $(100 \mathrm{mg} / \mathrm{kg}$ body weight, i.p.) and perfused transcardially with $200 \mathrm{ml}$ of Krebs-Ringer solution, followed by $200 \mathrm{ml}$ of modified Zamboni's solution (2\% paraformaldehyde and $75 \%$ saturated picric acid in $0.1 \mathrm{M}$ sodium phosphate, $\mathrm{pH} 7.2$ ) for $30 \mathrm{~min}$ at room temperature. The brains were quickly removed, cut into several blocks, and placed in the same buffer at $4{ }^{\circ} \mathrm{C}$ for $4 \mathrm{hr}$. After rinsing in ice-cold PBS containing $10 \%$ and then $20 \%$ sucrose, the blocks were frozen on dry ice and cut into frontal sections $40 \mu \mathrm{m}$ thick. The sections were collected in PBS and immunostained by the ABC method (Hsu et al., 1981). The incubation steps were as follows: (1) $10 \%$ normal goat serum for $1 \mathrm{hr}$; (2) monoclonal antibody $\left(10 \mu \mathrm{g} / \mathrm{ml}\right.$ in PBS-X) overnight at $4^{\circ} \mathrm{C}$ in the absence or presence of excess purified P $\Lambda \mathrm{G}(170 \mu \mathrm{g} / \mathrm{ml})$; (3) biotinylated anti-(mouse $\operatorname{IgM}) \operatorname{Ig}(2.3 \mu \mathrm{g} / \mathrm{ml})$ for $1 \mathrm{hr}$; and (4) ABC for $1 \mathrm{hr}$. Steps (1), (3), and (4) were carried out in PBS-X at room temperature, and the sections were rinsed with PBS-X after each incubation. The peroxidase was visualized by the incubation at room temperature for 30-60 min with Graham-Karnovski's solution.

In several animals, fixation was performed with Bouin's solution, 2$8 \%$ paraformaldehyde solution ( $\mathrm{pH} 7$ ), $2 \%$ paraformaldehyde solution (pH 7) containing $2 \%$ carbodiimide, or $0.2-2 \%$ glutaraldehyde. Of fixatives used in the present study, the modified Zamboni's solution gave the best result in immunostaining for PAG.

\section{Materials}

$\mathrm{L}^{-14} \mathrm{C}(\mathrm{U})$-glutamine ( $>200 \mathrm{mCi} / \mathrm{mmol}$ ) and $\mathrm{L}$-glutamine were purchased from New England Nuclear and Nakarai Chemicals, Kyoto, Japan, respectively. Before use, both were purified by passage through Dowex 1-X8 (acetate form) columns to remove glutamic acid. The sources of other materials used in this work were as follows: Sephacryl S-400, lysine-Sepharose, Sepharose 4B, and Con A-Sepharose from Pharmacia; nitrocellulose and Zeta-Probe membranes, and Dowex 1-X8 resin from Bio-Rad; complete and incomplete Freund's adjuvants from Difco; polyethylene glycol 4000 from Merck; RPMI 1640 medium from Gibco; fetal calf serum from M. A. Bio-products, MD; tissue culture dishes and microtiter plates from Falcon; Vectastain ABC kit, biotinylated anti-[mouse $\operatorname{IgG}(\mathrm{H}+\mathrm{L})] \mathrm{Ig}$ and biotinylated anti-(mouse $\mathrm{IgM}) \mathrm{Ig}$ from Vector Lab.; mouse myeloma IgM from Miles; rabbit anti-(mouse IgM) IgG from Medical and Biological Lab. (MBL), Aichi, Japan; goat anti-(rabbit IgG) serum from Cappel Lab.; and rabbit PAP from Dako. All other chemicals were of reagent grade.

\section{Results}

\section{Purification of $P A G$}

Purification of rat brain PAG is summarized in Table 1. About $70 \%$ of PAG activity in the crude homogenate was recovered in the mitochondrial fraction. The specific activity in the mitochondrial fraction $(0.17 \mathrm{U} / \mathrm{mg}$ protein) was about 3 -fold higher than that of the homogenate. PAG was solubilized from the crude mitochondrial fraction by using $1 \%$ Triton X-100 with slight activation (108\%). The remaining pellet had less than $1 \%$ of the initial activity. In the gel-filtration step on Sephacryl S-400 in $T$ buffer, the elution peak of PAG activity was retarded by about $1 / 3$ the bed volume from the void volume of the column. When the enzyme was incubated with phosphate and borate, it polymerized and was eluted in the void volume of gel filtration with Sepharose 4B in PB buffer. These properties of PAG were similar to those described in the purification of PAG from rat kidney (Curthoys et al., 1976) and pig brain (Nimmo and Tipton, 1980).

In the final step, PAG was purified 1000 -fold from the mitocondrial fraction with a recovery of $27 \%$, and about 3000 fold from the crude brain homogenate. The specific activity of the purified enzyme was $174 \mathrm{U} / \mathrm{mg}$ protein in the presence of $250 \mathrm{~mm}$ potassium phosphate and $15 \mathrm{~mm}$ boric acid, 168 in the presence of $250 \mathrm{~mm}$ potassium phosphate without borate. In the absence of both phosphate and borate, the purified enzyme was almost inactive $(<1 \mathrm{U} / \mathrm{mg}$ protein). The reaction product catalyzed by the purified enzyme exhibited the same mobility as that of glutamic acid on thin-layer chromatography. Thus, 

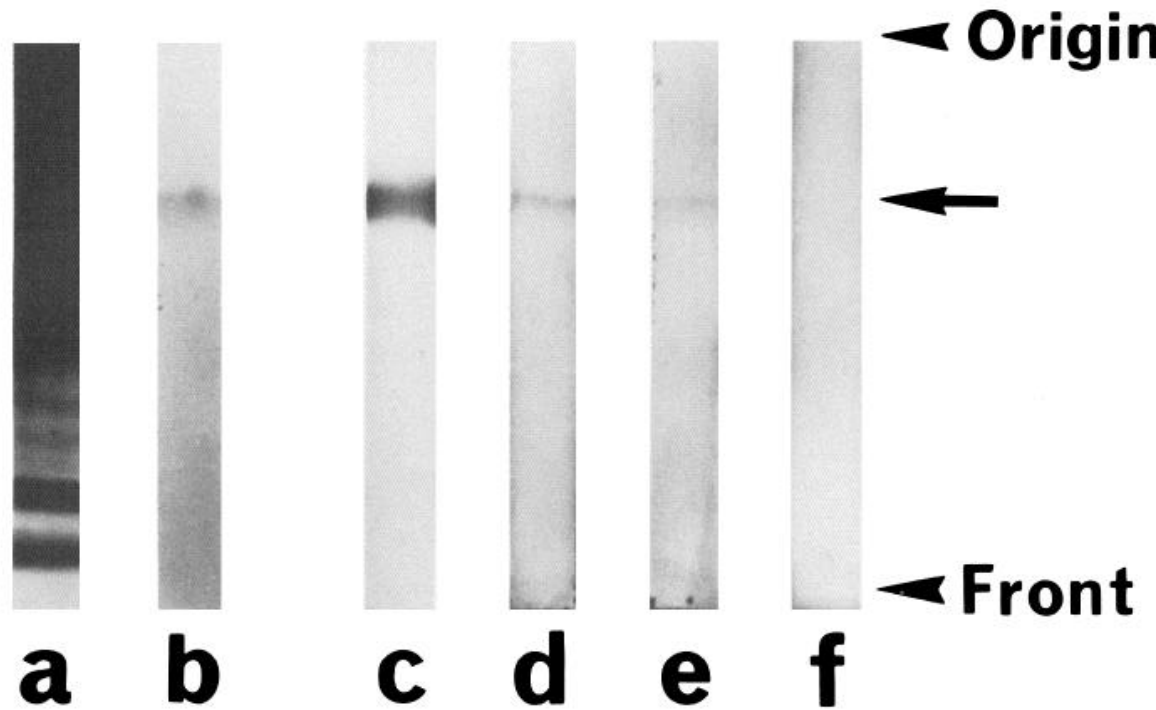

Figure 3. Immunoblotting with antiPAG monoclonal antibodies. Crude Triton X-100 extract from the rat brain $(50 \mu \mathrm{g} / \mathrm{lane}$; lanes $d-f)$ or purified enzyme $(0.2 \mu \mathrm{g} /$ lane; lane $c)$ was electrophoresed in a $7.5 \%$ polyacrylamide slab gel in the presence of $0.1 \%$ Triton X-100, blotted onto Zeta-Probe membrane, and then immunostained with $\mathrm{mAb}-21$ ( $c$ and $d$ ), mAb-19 $(e)$, or a control employing myeloma mouse IgM $(f)$. Proteins in the crude extract (a) or purified enzyme $(b)$ were stained in the gel with Coomassie Brilliant blue R-250. The position of the purified enzyme is indicated by an arrow. the purified enzyme showed the properties essential to phosphate-activated glutaminase.

In the presence of $250 \mathrm{~mm}$ phosphate and the absence of borate, the $K_{\mathrm{m}}$ value for glutamine and $\mathrm{pH}$ optimum were 5.0 $\mathrm{mm}$ and 8.7 , respectively. The purity of the preparation was checked by SDS-gel electrophoresis (Fig. 1). Only one band of protein was detected at the molecular weight 62,000 position.

\section{Monoclonal antibodies}

After 3 weeks of selection in HAT medium, $36 \%$ of the wells contained growing hybridomas. Out of 14 wells positive for antiPAG activity, 9 wells survived repetitive cloning. All cell lines secreted IgM. Two antibodies (mAb-19 and -21) purified from ascites fluids and/or culture media were used in the following experiments.

Immunotitrations of rat brain PAG with the antibodies are shown in Figure 2. PAG activity in the homogenate of the whole brain was completely extracted with $1 \%$ Triton X-100. The activity of the extract was absorbed with both antibodies, mAb19 and -21 , in a dose-dependent manner. The absorption activity of mAb-21 was a little higher than that of mAb-19. After incubation with an excess amount of the antibodies, PAG activity decreased to less than $10 \%$ of the initial activity. Therefore, these antibodies recognized at least $90 \%$ of PAG activity in the brain. When the crude extract was incubated with control mouse IgM, the enzyme activity in the supernatant was not absorbed.

Immunoblotting after $7.5 \%$ PAGE in the presence of $0.1 \%$ Triton X-100 revealed the specificity of both the antibodies (Fig. $3)$. Among many bands of protein in the Triton X-100 extract of the whole brain (lane a), mAb-19 and -21 recognized only 1 band (lanes e, d) at the same position as that of the purified enzyme (lanes b, c). In lane c, a weakly positive band is seen above the intensely stained band, which probably resulted from the tendency of the purified enzyme to polymerize, as mentioned by Nimmo and Tipton (1980). The finding in lanes $d$ and e means not only that the antibodies were specific for PAG, but also that PAG in the crude Triton X-100 extract had no heterogeneity on gel electrophoresis in the presence of Triton X-100. No positive band was detected in immunoblotting after SDSgel electrophoresis, suggesting that the enzyme lost the immu- noreactivity with the antibodies in the presence of SDS. The results of immunoblotting and immunotitration tests indicated that the 2 antibodies, mAb-19 and -21 , were specific and sufficient markers for PAG in the rat brain.

\section{Immunocytochemical application of monoclonal antibodies}

Immunohistochemical applicability of mAb-19 and -21 was examined using the cerebral neocortex of the rat, since there is a growing body of evidence indicating that at least some pyramidal cells in the neocortex are glutamatergic (Watkins and Evans, 1981; Fonnum, 1984; Donoghue et al., 1985). Many pyramidal cells were intensely labeled with mAb-21 in layer $\mathrm{V}$, moderately in layer VI, and slightly in the supragranular layer (Fig. 4a). The immunoreactivity of mAb-19 (Fig. $4 b$ ) was lower than that of mAb-21 (Fig. $4 c$ ), as expected from the results of the immunotitration (Fig. 2). When the antibody was reacted with an excess amount of purified PAG $(>170 \mu \mathrm{g} / \mathrm{ml})$ before incubation, no immunoreactive products were observed (Fig. 4d).

Immunohistochemical analysis with the antibody mAb-21 revealed that PAG-like immunoreactivity (PAG-LI) was observed in many neurons but not in glial cells or vessels in the rat brain. Neurons with intense PAG-LI were seen in the pontine nuclei, pontine tegmental reticular nucleus of Bechterew, lateral reticular nucleus of the medulla oblongata, and external cuneate nucleus (Fig. 5, $a-d$ ), as well as in layers V and VI of the cerebral neocortex. Possible axon terminals with PAG-LI were observed in the cerebellum and inferior olive: Small clusters of immunoreactive grains were scattered in the granular layer of the cerebellum (Fig. 5e). Immunoreactive fine grains were also distributed densely throughout the whole extent of the inferior olivary complex (Fig. $5 f$ ). No cell bodies, however, were labeled for PAG-LI in the inferior olivary complex.

\section{Discussion}

Phosphate-activated glutaminase has been purified from pig kidney (Kvamme et al., 1970), pig brain (Svenneby et al., 1973; Nimmo and Tipton, 1980), and rat kidney (Curthoys et al., 1976), but not from rat brain. We reported here the purification of solubilized PAG from rat brain mitochondria. Solubilization with Triton X-100 was a good extraction method (a yield of 

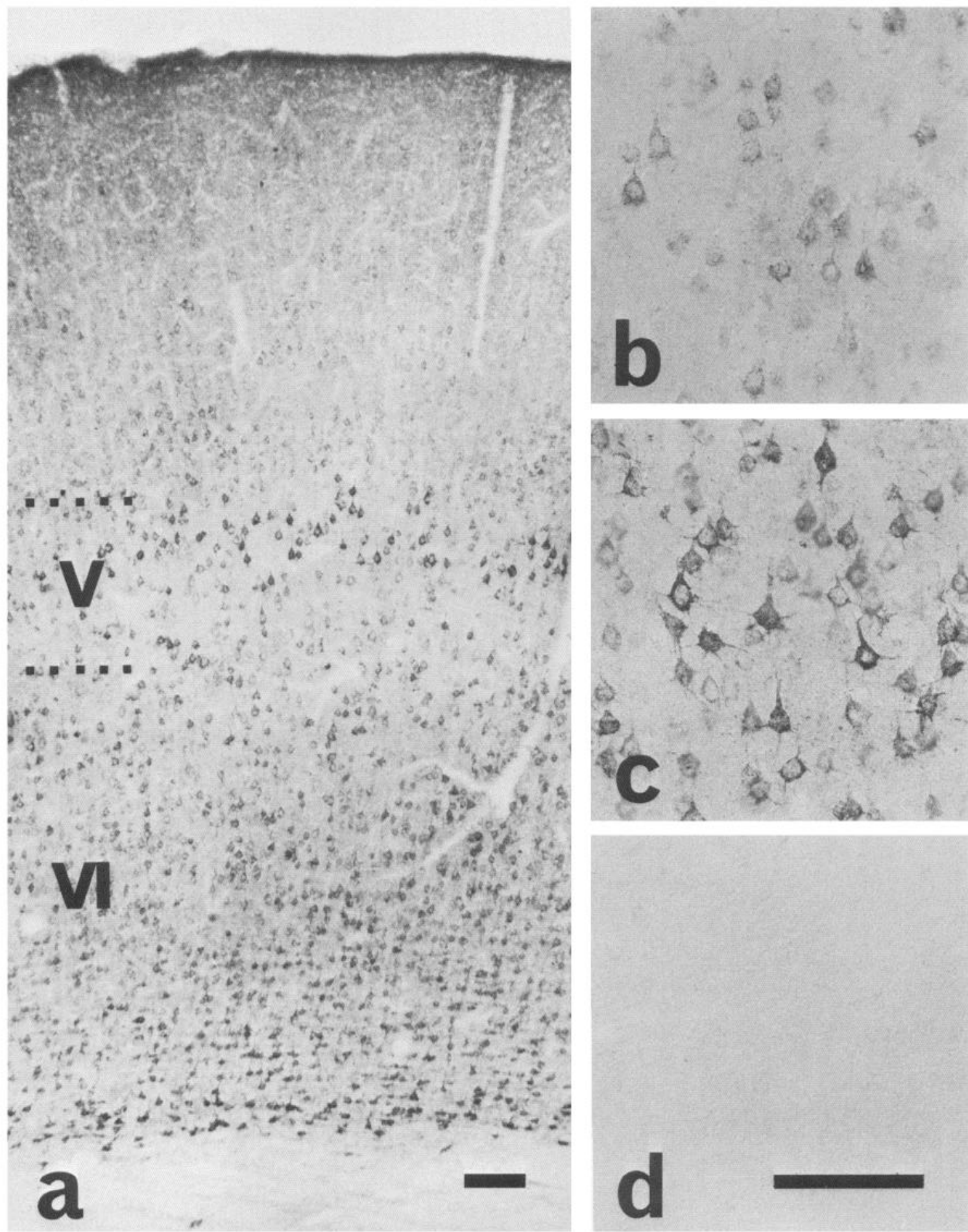

Figure 4. PAG-like immunoreactive neurons in the rat somatic sensorimotor cortex. Many neurons in layers V and VI were immunoreacted with $\mathrm{mAb}-21(a)$. Pyramidal cells in layer $\mathrm{V}$ were stained less intensely with mAb-19 $(b)$ than with mAb-21 $(c)$. No immunoreactivity is observed in the section incubated with mAb-21 in the presence of excess purified PAG $(d)$. Scale bar, $100 \mu \mathrm{m}$.

$108 \%$ ); this resulted in the highest yield (19\% from the homogenate) of the purification. On SDS-PAGE glutaminases purified from the kidney showed some heterogeneity (Kvamme et al., 1970; Shapiro et al., 1978), whereas brain enzymes were apparently homogeneous at molecular weights 63,900 (Svenneby et al., 1973), 73,000 (Nimmo and Tipton, 1980), and 62,000 (present study). Both the brain and kidney enzymes showed the property of polymerization in the presence of phosphate and borate and had a $\mathrm{pH}$ optimum in the range of 8.7-9.0.

As expected from the fact that PAG, the antigen, was extracted from the mitochondria with $1 \%$ Triton $\mathrm{X}-100$, the preincubation of the sections with $1 \%$ Triton X-100 before immunostaining led to the weakening of the immunoreactivity. On the other hand, if the sections were incubated with the antibodies 

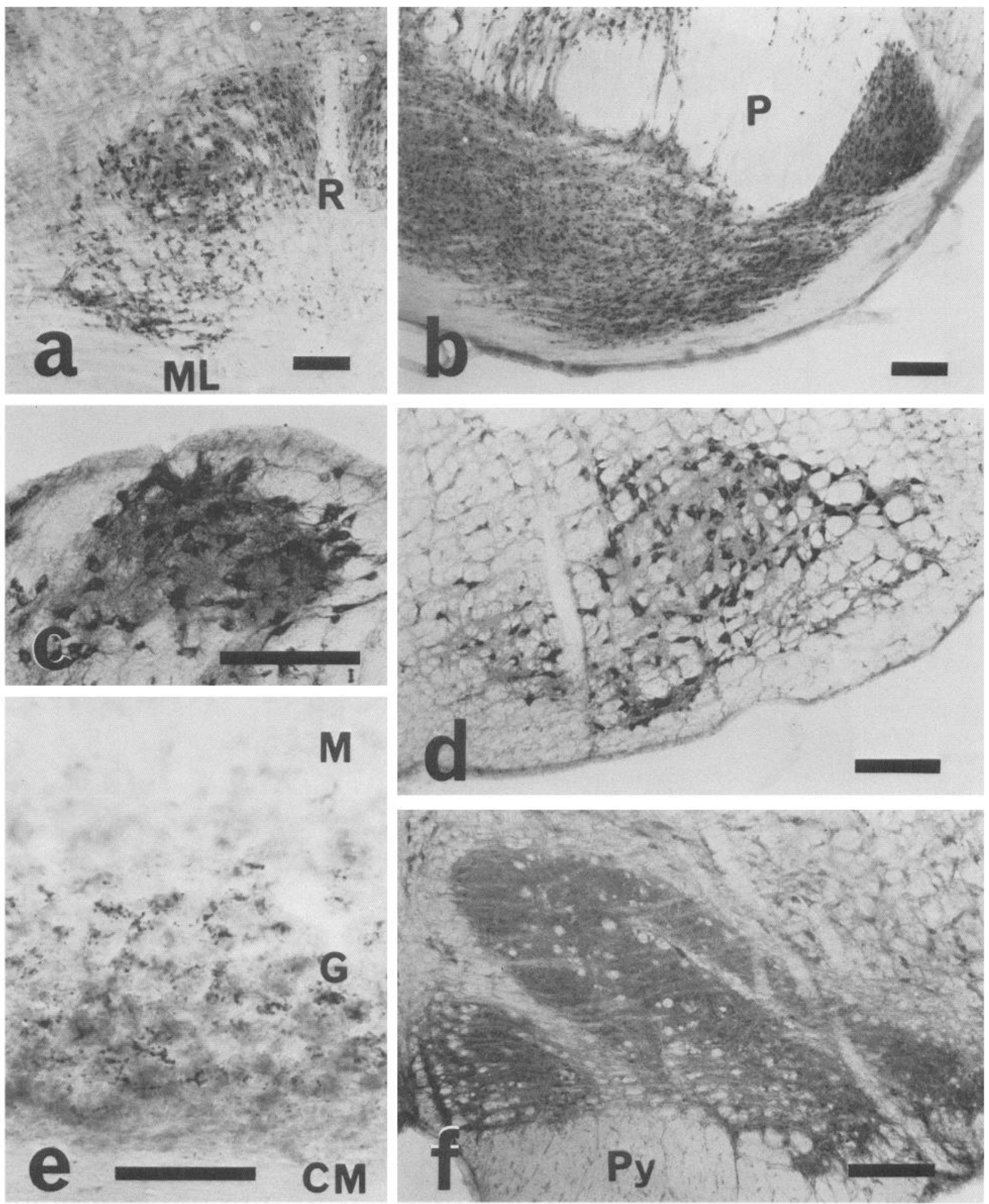

Figure 5. PAG-like immunoreactivity in the precerebellar nuclei and cerebellar cortex. Intensely labeled neuronal somata are seen in the pontine tegmental reticular nucleus of Bechterew $(a)$, pontine nuclei $(b)$, external cuneate nucleus $(c)$, and lateral reticular nucleus of the medulla oblongata $(d)$. Small clusters of grains, possible axon terminals, with PAG-LI are seen in the granular layer of the cerebellar cortex (e). Fine grains with PAGLI are densely distributed, but no cell bodies are seen in the inferior olivary nucleus $(f)$. $C M$, cerebellar medulla; $G$, granular layer; $M$, molecular layer; $M L$, medial lemniscus; $P$, pontine longitudinal fibers; $P y$, pyramidal tract; $R$, raphe. Scale bar, $200 \mu \mathrm{m}(a-d, f)$ or $50 \mu \mathrm{m}(e)$. 
in the absence of Triton X-100, no immunoreactivity was observed, probably because of the inaccessibility of the IgMs to PAG in the mitochondria. The best immunostaining for PAG was obtained when $0.3 \%$ Triton $\mathrm{X}-100$ was included in the incubation media.

The immunohistochemical experiments showed that pyramidal cells were intensely labeled with the monoclonal antibodies in layer $\mathrm{V}$ and moderately in layer VI of the cerebral neocortex of the rat. This result is consistent with the recent immunohistochemical study with the antiserum against rat renal PAG (Donoghue et al., 1985), and it supports the notion that some pyramidal cells in layers $\mathrm{V}$ and VI of the cerebral neocortex use glutamate as neurotransmitter (for reviews, Watkins and Evans, 1981; Fonnum, 1984; Donoghue et al., 1985).

Afferent fibers to the cerebellar cortex as generally divided into 3 categories; the first are climbing fibers, which originate from the inferior olivary complex to mediate excitatory inputs to Purkinje cells; the second are mossy fibers, which arise from the precerebellar nuclei other than the inferior olive to convey excitatory inputs to granule cells; and the last are monoaminergic afferents, which comprise noradrenergic fibers from the locus coeruleus and serotonergic fibers from the raphe nuclei (Eccles et al., 1967; Brodal, 1981; Ito, 1984). Climbing fibers originating from the inferior olive appear to contain aspartate as transmitter (Wiklund et al., 1982; Campistron et al., 1986). Although some mossy fibers have been reported to contain choline acetyltransferase (Kan et al., 1978), substance P (Inagaki et al., 1982a), or somatostatin (Inagaki et al., 1982b), candidate transmitters for the vast majority of mossy fibers are still unknown (Ito, 1984). The present study showed that small clusters of possible axon terminals with high PAG-LI were scattered in the granular layer of the cerebellar cortex and that many neuronal cell bodies with high PAG-LI existed in the pontine nuclei, pontine tegmental reticular nucleus of Bechterew, lateral reticular nucleus of the medulla oblongata, and external cuneate nucleus. All of these lower brain-stem nuclei are precerebellar nuclei sending mossy fibers to the cerebellar cortex (Eccles et al., 1967; Brodal, 1981; Ito, 1984). Thus, the present results indicate that some precerebellar neurons sending mossy fibers to the granular layer of the cerebellum use glutamate as excitatory neurotransmitter; glutamate has been reported to exert excitatory influences on most neurons (Krnjevic, 1974).

It has been suggested that granule cells in the cerebellar cortex use glutamate as a transmitter (Wenthold et al., 1986; for further review, see Ito, 1984). In the present study, however, no evidence suggested the presence of PAG-LI in the granule cells. This is probably because the antibodies are not sensitive enough to detect PAG in the granule cells, or because PAG is not involved in the synthesis of glutamate in granule cells.

\section{References}

Altshuler, R. A., R. J. Wenthold, A. M. Schwartz, W. G. Haser, N. P. Curthoys, M. H. Parakkal, and J. Fex (1984) Immunocytochemical localization of glutaminase-like immunoreactivity in the auditory nerve. Brain Res. 291: 173-178.

Bradford, H. F., H. K. Ward, and A. J. Tomas (1978) Glutamine-a major substrate for nerve endings. J. Neurochem. 30: 1453-1459.

Bradford, H. F., H. K. Ward, and C. M. Thanki (1983) Glutamine as a neurotransmitter precursor: Complementary studies in vivo and in vitro on the synthesis and release of transmitter glutamate and GABA. In Glutamine, Glutamate, and GABA in the Central Nervous System, L. Hertz, E. Kvamme, E. G. McGeer, and A. Shousboe, eds., pp. 249-260, Liss, New York.
Brodal, A (1981) Neurological Anatomy in Relation to Clinical Medicine, Oxford U. P., New York.

Campistron, G., R. Buijs, and M. Geffard (1986) Specific antibodies against asparatate and their immunocytochemical application in the rat brain. Brain Res. 365: 179-184.

Curthoys, N. P., T. Kuhlenschmidt, and S. S. Godfrey (1976) Regulation of renal ammoniogenesis. Purification and characterization of phosphate-dependent glutaminase from rat kidney. Arch. Biochem. Biophys. 174: 82-89.

Davis, B. J. (1964) Disc clcctrophorcsis-II. Mcthod and application to human serum protein. Ann. NY Acad. Sci. 121: 404-427.

Donoghue, P. J., R. J. Wenthold, and R. A. Altshuler (1985) Localization of glutaminase-like and aspartate aminotransferase-like immunoreactivity in neurons of cerebral neocortex. J. Neurosci. 5: 25972608.

Eccles, J. C., M. Ito, and J. Szentágothai (1967) The Cerebellum as a Neuronal Machine, Springer-Verlag, Berlin.

Fonnum, F. (1984) Glutamate: A neurotransmitter in mammalian brain. J. Neurochem. 42: 1-11.

Graham, R. C., and M. J. Karnovski (1966) The early stages of absorption of injected horseradish peroxidase in the proximal tubules of mouse kidney: Ultrastructural cytochemistry by a new technique. J. Histochem. Cytochem. 14: 291-302.

Greenamyre, J. T., A. B. Young, and J. B. Penny (1984) Quantitative autoradiographic distribution of $\mathrm{L}-\left[{ }^{3} \mathrm{H}\right]$ glutamate-binding sites in rat central nervous system. J. Neurosci. 4: 2133-2144.

Halpain, S., C. M. Wiezorek, and T. C. Rainbow (1984) Localization of $\mathrm{L}$-glutamate receptors in rat brain by quantitative autoradiography. J. Neurosci. 4: 2247-2258.

Hamberger, A., G. H. Chiang, E. S. Nylen, S. W. Scheff, and C. W. Cotman (1979a) Glutamate as a CNS neurotransmitter. I. Evaluation of glucose and glutamine as precursors for the synthesis of preferentially released glutamate. Brain Res. 168: 513-530.

Hamberger, A., G. H. Chiang, E. Sandvall, and C. W. Cotman (1979b) Glutamate as a CNS neurotransmitter. II. Regulation of synthesis in the releasable pool. Brain Res. 168: 531-541.

Hsu, S.-M., L. Raine, and H. Fanger (1981) Use of avidin-biotinperoxidase complex (ABC) in immunoperoxidase techniques: A comparison between $\mathrm{ABC}$ and unlabeled antibody (PAP) procedures. J. Histochem. Cytochem. 29: 577-580.

Inagaki, S., M. Sakanaka, S. Shiosaka, E. Senba, H. Takagi, K. Takatsuki, Y. Kawai, T. Matsuzaki, H. Iida, Y. Hara, and M. Tohyama (1982a) Experimental and immunohistochemical studies on the cerebellar substance $\boldsymbol{P}$ of the rat: Localization, postnatal ontogeny and ways of entry to the cerebellum. Neuroscience 7: 639-645.

Inagaki, S., S. Shiosaka, K. Takatsuki, H. Iida, M. Sakanaka, E. Senba, Y. Hara, T. Matsuzaki, Y. Kawai, and M. Tohyama (1982b) Ontogeny of somatostatin-containing neuron system of the rat cerebellum including its fiber connections: An experimental and immunohistochemical analysis. Dev. Brain Res. 3: 509-527.

Ito, M. (1984) The Cerebellum and Neural Control, Raven, New York. Johnstone, A., and R. Thorpe (1982) Immunochemistry in Practice, pp. 56-59, Blackwell Scientific, Oxford, U.K

Kan, K.-S. K., L.-P. Chao, and L. F. Eng (1978) Immunohistochemical localization of choline acetyltransferase in rabbit spinal cord and cerebellum. Brain Res. 146: 221-229.

Köhler, G., and C. Milstein (1975) Continuous culture of fused cells secreting antibody of predefined specificity. Nature 256: 495-497.

Krnjevic, K. (1974) Chemical nature of synaptic transmitter in vertebrates. Physiol. Rev. 54: 418-540.

Kvamme, E. (1983) Deaminases and amidases. In Handbook of Neurochemistry, Vol. 4, A. Lajtha, ed., pp. 85-111, Academic, New York.

Kvamme, E., B. Tveit, and G. Svenneby (1970) Glutaminase from pig renal cortex. I. Purification and general properties. J. Biol. Chem. 245: 1871-1877.

Laemmli, U. K. (1970) Cleavage of structural proteins during the assembly of the head of bacteriophage T4. Nature 227:680-685.

Lowry, O. H., N. J. Rosenbrough, A. L. Farr, and R. J. Randall (1951) Protein measurement with the Folin phenol reagent. J. Biol. Chem. 193: 265-275.

Neidle, A., C. J. Van den Bery, and A. Grynbaum (1969) The heterogeneity of rat brain mitochondria isolated on continuous sucrose gradients. J. Neurochem. 16: 225-234.

Niederwieser, A. (1972) Thin layer chromatography of amino acids and derivatives. Methods Enzymol. 25: 60-99. 
Nimmo, G. A., and K. F. Tipton (1980) Purification of soluble glutaminase from pig brain. Biochem. Pharmacol. 29: 359-367.

Otterson, O. P., and J. Storm-Mathisen (1984) Glutamate- and GABAcontaining neurons in the mouse and rat brain, as demonstrated with a new immunocytochemical technique. J. Comp. Neurol. 229: 374 392.

Prusiner, S., and L. Milner (1970) A rapid radioactive assay for glutamine synthetase, glutaminase, asparagine synthetase, and asparaginase. Anal. Biochem. 12: 287-309.

Reubi, J. C. (1980) Comparative study of the release of glutamate and GABA, newly synthesized from glutamine in various regions of the central nervous system. Neuroscience $5: 2145-2150$.

Reubi, J. C., C. Van der Berg, and M. Cuénod (1978) Glutamine as precursor for the GABA and glutamate transmitter pools. Neurosci. Lett. 10: 171-174.

Salganicoff, L., and E. De Robertis (1965) Subcellular distribution of the enzymes of the glutamic acid, glutamine and $\gamma$-aminobutyric acid cycle in rat brain. J. Neurochem. 12: 287-309.

Shapiro, R. A., V. M. Clark, and N. P. Curthoys (1978) Covalent interaction of L-2-amino-4-oxo-5-chloropentanoic acid with rat renal phosphate-dependent glutaminase. J. Biol. Chem. 253: 7086-7090.

Sternberger, L. A. (1979) Immunocytochemistry, 2nd ed., pp. 104169 , Wiley, New York.

Svenneby, G., I. Aa. Torgner, and E. Kvamme (1973) Purification of phosphate-dependent pig brain glutaminase. J. Neurochem. 20:12171224.

Watkins, J. C., and R. H. Evans (1981) Excitatory amino acid transmitters. Annu. Rev. Pharmacol. Toxicol. 21: 165-204.

Weinstein, Y., G. David, and P. H. Strausbauch (1972) The fractionation of immunoglobulins with insolubilized concanavalin A. J. Immunol. 109: 1402-1404.

Wenthold, R. J., K. Skaggs, and R. A. Altshuler (1986) Immunohistochemical localization of aspartate aminotransferase and glutaminase immunoreactivities in the cerebellum. Brain Res. 363: 371-375.

Wiklund, L., G. 'Toggenburger, and M. Cuénod (1982) Aspartate: Possible neurotransmitter in cerebellar climbing fibers. Science 216:6980. 